\title{
HASRAT KEBEBASAN TOKOH 'KAU' DALAM NOVEL GENTAYANGAN KARYA INTAN PARAMADITHA
}

\author{
Yessy Hermawati dan Siska Sintia Devi \\ Universitas Islam Nusantara \\ yessy.hermawati@gmail.com
}

ABSTRAK

ABSTRACT

PENDAHULUAN
Gentayangan merupakan novel karya Intan Paramaditha. Novel ini menghadirkan narasi yang berbeda dengan novel umumnya, dimana pembaca diberikan pilihan untuk menentukan jalan ceritanya sendiri. Intan, melalui novelnya, mengajak pembaca berperan melalui tokoh 'Kau'. Tak hanya pembaca yang dapat bebas memilih, tokoh 'Kau' juga mengalami petualangan sebagai bentuk hasratnya terhadap pencarian dirinya. Penelitian ini bertujuan untuk mendiskripsikan hasrat kebebasan Tokoh 'Kau'. Hasrat terbentuk dari rasa kekurangan subjek, melakukan petualangan merupakan upaya untuk mengisi kekurangan itu. Analisis novel ini menggunakan pendekatan psikoanalisis Lacan, metafora dan metominia digunakan untuk dapat melihat lebih dalam tentang hasrat kebebasan tokoh 'Kau'. Dari hasil pembahasan maka ditemukan tiga jenis hasrat kebebasan yang direpresentasikan pada tokoh 'kau' dan terlihat melalui tiga jalur pilihan dalam novel ini yaitu, kebebasan melakukan perjalanan, kebebasan yang memiliki resiko, dan kebebasan yang dapat dibagi kepada sesamanya.

Kata Kunci: Gentayangan, Hasrat kebebasan, psikoanalisis, Jacques Lacan

Gentayangan is a works of Intan Paramaditha. This works presents a unique plot that is different from the others works. The readers of Gentayangan could choose their plot and their own story. Intan through her works persuade the readers to play a role as the main character in the stories. The main Character called by 'Kau', have an adventure as desire manisfestation of her self. This study aims to describe desire of freedom from the main character 'Kau'. In its story, a desire comes from the feelings of the lack of subject, and having an advanture becomes an effort to fullfil the lack ini her self. This study uses Lacanian Psychoaalysis approaches, Methapor and Metonymy will be used through anlysis in looking deeply the desire of freedom of 'Kau'. This study finds out that there are three types of freedom represented by character called 'kau' through three different tracks of the story. They are freedom of going to an adventure, freedom with a risk, and dividing freedom.

Keywords: Gentayangan, desire of freedom, Jacques Lacan, psychoanalysis

Intan Paramaditha seorang penulis perempuan yang karyanya berfokus pada isu gender, seksualitas, budaya dan politik. Intan 
dikenal lewat Sihir Perempuan, kumpulan cerpen yang masuk dalam nominasi cerita pendek Khatulistiwa Literary Award (Kusala Sastra Khatulistiwa) pada tahun 2005. Setelah itu ia produktif menulis dan melahirkan karya seperti, Kumpulan Budak Setan yang ditulisnya bersama Eka kurniawan dan Ugoran Prasad pada tahun 2010, Klub Solidaritas Suami Hilang terbit dalam harian Kompas edisi tahun 2013, hingga yang terbaru Apple and Knife kumpulan cerpen yang diterjemahkan oleh Stephen J. Epstein.

Karya-karya Intan Paramaditha umumnya bergenre horor hal itu dipengaruhi oleh bacaan yang ia sukai yaitu karya Margaret Atwood dan Angela Carter. Intan Paramaditha juga sangat pandai dalam menyuguhkan cerita-cerita lama, Ia terinspirasi dari proses yang dilakukan Mary Shelley dan Margaret Atwood dengan; membaca, memberi interpretasi berbeda, dan menyodorkan teks baru. Intan Paramaditha juga belajar dari Shelley, Atwood dan Carter bahwa membaca dan menulis ulang adalah strategi feminis. Pola tersebut dapat kita temui pada novel Gentayangan.

Intan Paramaditha dalam karyanya selalu memunculkan tematema yang gelap, horor, pembunuhan, kematian dan tabu. Gentayangan memunculkan cerita yang menarik, karena Gentayangan merupakan sebuah novel petualangan dengan sedikit sentuhan sisi gelap dan horor khas Intan. Petualangan yang Intan suguhkan dalam Gentayangan merupakan pengalaman pribadinya saat sedang melakukan perjalanan berpindah-pindah kota dan negara dalam satu dekade terakhir. Hal itu tentu mempengaruhi pemikiran Intan mengenai globalisasi dan batas-batas negara.

Novel Gentayangan menyuguhkan sesuatu yang berbeda dari karya-karya Intan sebelumnya. Dalam novel ini Pembaca dibebaskan untuk memilih jalan ceritanya sendiri dan mengakhiri ceritanya sendiri. Setiap orang bebas merasakan apa yang ingin ia rasakan. Gentayangan juga memunculkan beberapa narasi kolektif yang ditemui oleh tokoh 'kau' dari tokoh lain.

Tokoh 'Kau' memulai perjalanannya dengan membuat perjanjian dengan iblis kekasih. 'Kau' mulai melakukan petualangan untuk memenuhi hasratnya akan sebuah kebebasan. Di tengah perjalanan ia bertemu dengan beberapa orang yang menceritakan kebebasan atas diri tokoh tersebut. Perjalanan hidup tokoh 'Kau', merupakan perjalanan yang Ia pilih sendiri tanpa ada paksaan dari orang lain. 'Kau' menentukan atas apa yang ia inginkan terhadap dirinya sendiri.

Gaya narasi cerita yang berbeda, mengantarkan posisi tokoh 'Kau', kepada pembaca sehingga pembacaah yang menjadi subjek ceritanya. Dengan membaca novel ini, pembaca diajak untuk mengalami pengalaman-pengalaman dan petualangan dalam cerita itu, salah satunya tentang kebebasan diri. Mengkaji tentang kebebasan merupakan pengalaman untuk memahami diri secara psikologis dan sosial. Hal ini yang menarik dan penting untuk dibicarakan.

Tokoh 'Kau' dihadirkan diawal cerita sebagai tokoh yang selalu merasa hidupnya membosankan. Bahkan dalam novel 
diceritakan bahwa tokoh 'Kau' tidak menginginkan menjadi dirinya sendiri ataupun orang lain. 'Kau' menginginkan sebuah kebebasan yang direpresentasikan dengan cara berpetualang. Petualangan sebagai suatu kebebasan akan dirinya, akan tetapi setelah melakukan petualangan ia malah mendapati bahwa dirinya terus merasa kekuarangan. Konsep tentang kekurangan diri juga dibahas dalam konsep psikoanalisis Lacan. Sebagaimana yang diungkapkan Lacan (Lacan, 2001) bahwa terdapat peristiwa di mana subjek semakin sadar kekurangan yang ada di dalam dirinya, sehingga dia terus menerus ingin diisi dan dipenuhi. Kekurangan ini mengintensifikasi desire sebagai leftover dari kebutuhan. Jika kebutuhan bisa terpenuhi, maka desire adalah sisa dari kebutuhan yang tidak bisa terpuaskan.

Dalam petualangannya tokoh 'Kau' selalu melakukan pencarian akan dirinya sendiri. Terkadang ia bingung, mau seperti apa dan apa yang ia inginkan. Ia tetap tidak merasakan keutuhan akan dirinya sendiri. Sebagaimana yang diungkapkan (Sarup, 2011) Lacan berpendapat bahwa tidak ada subjek kecuali dalam representasi serta tidak ada representasi yang dapat merangkum diri kita secara utuh dan saya juga tidak dapat melepaskan diri dari semua definisi yang ada. Saya adalah proses pencarian menuju diri yang sejati. Cara kita menampilkan diri selalu menjadi subjek penafsiran orang lain. Di sisi lain, semua upaya totalitas orang lain, untuk memahami orang lain secara utuh, pasti akan mengalami kegagalan--tidak ada penggambaran yang adil bagi orang lain.

Lacan melalui (Manik, 2016) mengatakan bahwa apa yang menggerakkan kehidupan manusia adalah hasrat. Tokoh 'Kau' menginginkan kebebasan dalam hidupnya. Hal itu menunjukan bahwa kebebasan tersebut juga didorong oleh hasrat yang terbentuk dalam tokoh 'Kau'. Hasrat kebebasan tersebut direpresentasikan lewat bahasa. Lacan lalu menjelaskan, "for the symptom is a metaphor whether one likes it or not, as desire is a metonymy, however funny people may find the idea" (Lacan, 2001). Artinya bahasa adalah gejala tubuh yang tidak terpuaskan, sehingga bahasa selalu bersifat metaforik, sedangkan desire adalah metonimi atau substitusi dari penanda ke penanda yang lain yang tak pernah usai. Sebagaimana yang diungkapkan oleh Hartono (2007, hal. 26-27) dalam mendefinisiskan subjek bahasa merupakan jejaring kultural yang paling dominan. Lacan mengatakan, subjek ditentukan oleh bahasa, subjek tidak mungkin ada tanpa bahasa. Dengan kata lain, tidak ada subjek yang bebas dari bahasa. Subjek tenggelam kedalam bahasa dan subjek tidak pernah lepas dari bahasa seharihari. Manusia merepresentasikan dirinya melalui bahasa. Bahasa merupakan jalan menuju domain sosial.

Tokoh 'Kau' mengungkapkan keinginan kebebasannya melalui bahasa. Penulis tidak langsung menuliskan secara gamblang kebebasan yang ia inginkan. Penulis menggunakan metafora dan metonimia dalam menyalurkan hasratnya. Bracher (2009) menyatakan metafora dan metonimia adalah dua jenis negosiasi utama yang berlangsung pada penanda-penanda. Dalam pemikiran 
Lacan, metonimia merupakan cara bagaimana penanda-penanda itu terhubung dengan penanda lain dalam sebuah rantai yang akhirnya dengan seluruh jaringan memberikan jalur tempat bekerjanya identifikasi dan hasrat. Sedangkan, Metafora yang menurut Lacan merupakan sumber point-de-capiton muncul saat sebuah pemaknaan yang ada pada ketidaksadaran "mengubah, mengatur penggunaan penanda, sampai pada satu titik dimana setiap hubungan jenis leksikal yang sudah ada sebelumnya dipersatukan.”

Lacan melalui (Rahimi, 2009) berpendapat metonimia yaitu hubungan antara kata dengan kata, kemudian formula dari metafor yaitu satu kata untuk kata yang lain. Bahasa (penanda) menjadi tujuan penting dalam kajian psikoanalisis Lacan sebab ketidaksadaran terstruktur seperti bahasa yang memainkan peranannya di dalam metafora dan metonimia. Dalam perspektif Lacan, Seperti yang dikemukan oleh (Faruk, 2012, hal. 197) memahami karya sastra adalah usaha untuk menemukan ketidaksadaran subjek dalam mencari keutuhan atau kepenuhan dirinya. Sehingga kondisi ketidaksadaran tidak mungkin diakses sepenuhnya maka untuk dapat memahami karya sastra dilihat melalui bahasa dengan memperhatikan metafora dan metonimia yang ada pada karya sastra tersebut. Dengan menggunakan metafora dan metonimia dapat ditemukan bagaimana gambaran hasrat kebebasan tokoh 'Kau'.

Penelitian ini bertujuan untuk melihat bagaimana gambaran kebebasan diri seseorang serta perjalanan untuk menemukan kebebasan itu sendiri. Tujuan tersebut dilihat melalui hasrat yang ada pada diri tokoh 'kau' dalam novel Gentayangan. Pembahasan mengenai sebuah hasrat kebebasan menarik untuk dikaji melalui pendekatan psikoanalisis karena dapat menjabarkan sesuatu hal yang misterius dan rumit dan abstrak, dan mememahaminya dalm reaitas. Selain itu (Minderop,2016) juga mengungkapkan bahwa membahas karya satsra dengan pendekatan psikoanalisis tidak menghasilkan segalanya menjadi jelas, melainkan membuka suatu wilayah yang tak pasti yakni wilayah hasrat tak sadar mealui arti yangmungkin jelas. Dengan mengkaji hasrat dalam novel ini melalui bahsa yang digunakan penulisnya maka, kita dapat memahami tentang hasrat dan kebebasan yang direpresentasikan sebagai hasrat manusia,dengan ini kita juga dapat memahami dan menghargai kebebasan yang dimiliki orang lain. Untuk mencapai hal tersebut, penulis menggunakan pendekatan psikoanalisis Jacques Lacan.

\section{METODE}

Pendekatan yang digunakan dalam penelitian ini adalah kajian psikoanalisis. Psikologi sebagai pendekatan yang membahas mengenai psikis seseorang. Dalam kajian ini yang menjadi fokus kajian tokoh 'Kau' yang merupakan representasi sebuah hasrat dari Intan Paramaditha sebagai pengarang novel Gentayangan. Teori atau konsep yang digunakan yaitu psikoanalisis Jacques Lacan. Lacan melihat hasrat dari segi bahasa dengan mengidentifikasi metafora dan metonimia dalam karya sastra. 
Metode penelitian yang digunakan dalam penelitian ini yaitu metode analisis isi. Teknik ini dilakukan dengan cara pembacaan dan penandaan data pada novel Gentayangan. Penandaan itu dilihat dari unsur bahasa yaitu menganalisis berdasarkan metafora dan metonimia yang berkaitan dengan hasrat yang ditunjukan dalam novel Gentayangan.

Selanjutnya, teknik analisis dilakukan dengan cara menginterpetasi data yang berupa kutipan yang dikaitkan dengan hasrat kebebasan yang dihadirkan tokoh 'kau' dalam novel Gentayangan karya Intan Paramaditha. Sumber data yang digunakan dalam penelitian ini adalah novel Gentayangan: Pilih Sendiri Petualangan Sepatu Merahmu Karya Intan Paramaditha yang diterbitkan oleh PT Gramedia Pustaka Utama, Jakarta. Novel ini merupakan cetakan pertama tahun 2017 dengan jumlah halaman 492.

\section{PEMBAHASAN}

Untuk dapat melihat representasi hasrat kebebasan tokoh 'Kau', maka perlu dipahami cerita demi cerita di dalam novel Gentayangan. Bagaimana tokoh 'kau' mengungkapkan atau mengartikan sebuah hasrat kebebasan akan dirinya. Kebebasan tersebut direpresentasikan melalui bahasa yang kita pahami dengan cara melihat metafora dan metonimia Lacan dalam novel Gentayangan.

Penulis membuat tokoh 'kau' agar pembaca dapat merasakan langsung hal apa yang akan terjadi kepada pembaca, yaitu suatu kebebasan yang 'Kau' wujudkan lewat tindakannya dalam memilih dan menerima resiko dari hal tersebut. Resiko yang tidak ditakuti oleh tokoh 'Kau' karena pilihannya adalah sebuah kebebasan akan dirinya. Hasrat mengenai kebebasan dapat dilihat dalam kutipan berikut,

"Kau terkutuk untuk bertualang, atau lebih tepatnya, gentayangan. Bernaung, tapi tak berumah. Di tempat kau berasal, hantu gentayangan Cuma bisa beristirahat dengan tenang setelah dukun merapal mantra atau kiai berkomatkamit membaca Al Fatihah. Biarlah kutegaskan bahwa di sini tak ada dukun atau kiai yang terlibat, sebab ini permainanku, dan kau juga terkutuk.

Tapi mungkin ini sesuai dengan keinginanmu. Tiket sekali jalan. Dalam perjalananmu, kau akan mendengar banyak cerita, dan kau akan memungut hadiah. Satu hadiah untuk satu cerita, begitu kira-kira. Kau boleh memilih hadiah, juga jalan cerita, sesuai keinginanmu.” (Paramaditha, 2017, hal. 7-8)

Dalam teks di atas, 'bertualang' 'gentayangan' 'bernaung tapi tak berumah' 'keinginanmu' 'perjalananmu' 'kau boleh memilih hadiah, juga jalan cerita, sesuai keinginanmu’ merupakan objekobjek penanda yang menunjukan petualangan, petualangan tersebut menandakan hasrat kebebasan tokoh 'kau'. Petualangan pada kutipan di atas, menunjukan bahwa petualangan yang akan ia jalani 
merupakan petualangan tanpa batas. Di mana 'kau' dapat pergi kemanapun tanpa menetap dalam waktu yang lama.

"Kau menunggu di Stasiun kereta bawah tanah Sutphin Boulevard. Akhirnya kau temukan stasiun itu setelah bertanya pada sekian banyak orang dan melewati beberapa toko. Kau sempat masuk ke salah satunya dan membeli sepasang sepatu. Toko itu seperti tak punya selera dan menjual barang-barang murahan. Tak apa. Sesampainya di pusat kota kau akan berbelanja seperti orang gila. Stasiun Sutphin Boulevard yang dingin dan suram diramaikan oleh orang-orang yang menunggu kereta untuk pergi kerja. Beberapa orang yang membawa koper atau ransel besar mungkin sama sepertimu: baru saja meluncur dari Bandara JFK.” (Paramaditha, 2017, hal. 21)

Kutipan di atas, merupakan objek-objek yang menandakan hasrat kebebasan tokoh 'kau'. Hasrat tokoh 'kau' direpresentasikan melalui metonimia sebagai berikut, 'Stasiun kereta Sutphin Boulevard' 'koper atau ransel besar' 'kereta' 'Bandara JFK'. Dari keempat metonimia tersebut, terdapat penanda 'Stasiun kereta Sutphin Boulevard' yang menandakan sebuah tempat untuk singgah dan menentukan perjalanan selanjutnya.

Di rumahmu anak-anak dianggap tak punya suara, tak punya selera. Buat ibu-bapakmu, kau dan kakakmu cukup terhibur dengan setumpuk VHS serial Pendekar Rajawali Sakti, atau film horor Indonesia tentang hantu Sundel Bolong yang makan 200 tusuk sate dan sepanci soto tanpa menjadi gemuk karena punggungnya bolong. Di rumah temanmu baru kau paham bahwa, di kelas sosial berbeda, selera anak bisa dianggap serius. (Paramaditha, 2017, hal. 88)

Penanda-penanda yang menjadi hasrat kebebasan dalam kutipan di atas dapat dilihat dari metonimia, 'dianggap tak punya' 'suara' 'selera' 'cukup terhibur' objek-objek tersebut menunjukan bahwa tokoh 'kau' dan kakaknya terkekang. Kehendak mereka selalu di atur oleh kedua orangtuanya, mereka hanya menurut dan menyimpan keinginanan tersebut. Keinginan yang tokoh kau pendam lama kelamaan berubah menjadi sebuah hasrat untuk mencari kebebasan. Hal tersebut juga didukung oleh kata-kata 'di rumah temanmu' seperti pada kutipan di atas yang menandakan teman tokoh 'kau' memiliki kebebasan tidak seperti dirinya.

Sampai lulus SMA, kau yakin bisa keluar dari dinding serba biasa yang mengurungmu. Kau belajar dan menabung dengan giat. Sewaktu-waktu kau harus pergi ke Singapura,

seperti yang lazim dilakukan geng borju di sekolahmu. (Paramaditha, 2017, hal. 13)

Pada kutipan berikutnya, 'yakin' 'keluar' 'dinding serba biasa yang mengurungmu' 'belajar' 'menabung' 'harus pergi' merupakan objek-objek penanda yang menunjukan bahwa tokoh 'kau' mulai 
menyadari keinginannya akan sebuah kebebasan yang harus ia dapatkan. Tokoh 'kau' sudah memikirkan dan menginginkan sebuah kebebasan tersebut. Hal itu bisa dijadikan sebuah representasi keinginan dan kebebasan dirinya. 'kau' mulai menyadari bahwa dirinya harus melewati keterbatasan yang menghalangi kebebasannya. Ia berusaha untuk melampaui batasan itu dengan membulatkan tekad dan bekerja keras. Ia tak mau terus menerus berada dalam keterbatasannya.

“... Di luar apapun, kau bersimpati pada semua yang terkutuk menjaga kebun, baik yang bisa bicara maupun yang bisu. Siapapun pasti berharap diculik, atau diberi sepatu merah yang membawa mereka jalan-jalan.” (Paramaditha, 2017, hal. 90-91).

'Berharap diculik' 'membawa jalan-jalan' merupakan objekobjek penanda metonimia yang menunjukan keinginan 'kau' untuk bebas. 'diberi sepatu merah' merupakan metafora dari kesempatan untuk mencapai suatu kebebasan dengan petualangan. Hal tersebut menegasakan bahwa setiap orang berhak atas suatu kebebasan yang harus mereka rasakan.

Di dalam perjalanannya, Narasi kolektif muncul dari orangorang yang ditemui tokoh 'kau', narasi tersebut memunculkan gagasan tentang sebuah kebebasan yang dirasakan oleh tokoh lain. Kebebasan yang diartikan berbeda-beda oleh setiap orang. Hal ini dapat terlihat pada salah satu kutipan berikut.

Di meja makan Meena, bumbu-bumbu membawamu bertualang. Meena tidak hanya berbicara tentang bumbu masala yang pedas, sebuah rujukan atas rumah. Ia juga bicara tentang petualangan. Tentang dunia. Ia mengikuti jejak bumbu-bumbu, menolak batas-batas negara. Ia gembira saat memasukkan daun basil ke dalam masakan Thailand dan Italia, atau ketika menemukan betapa minyak wijen memperkaya masakan Cina, Korea, dan Jepang secara berbeda. Ia mengingatkan bahwa tempatmu telah digariskan oleh pala. New York ditukar dengan Pulau Run di Banda oleh Belanda, dan karenanya sah sudah jejakmu di dunia. (Paramaditha, 2017, hal. 219)

Pada kutipan di atas, 'membawamu' 'berpetualang' 'gembira' 'memperkaya' merupakan objek-objek yang menandakan bahwa kebebasan telah di rasakan oleh tokoh Meena. 'Menolak batasbatas' merupakan metafora dari sikap Meena melawan keterbatasan yang menghalangi dirinya. Meena telah melewati batasan yang ada dan melampauinya. Meena menceritakan kebebasan dirinya kepada 'kau' dan membuat 'kau' terinspirasi dan menyadari kebebasan akan dirinya. Hal tersebut membuat tokoh 'kau' tertarik kepada Meena, karena 'kau' belum mendapatkan kebebasan yang Meena rasakan. Hal itu diperkuat oleh kutipan,

"Apakah semua ini mulai terasa membosankan? Tak ada petualangan. Kau tertarik pada Meena karena tak ada hal 
yang mendebarkan terjadi. Hidupmu di New York ternyata biasa-biasa saja dan kau mulai mencari keasyikan dalam peristiwa sehari-hari” (Paramaditha, 2017, hal. 195).

Tokoh 'kau' mulai menyadari kekurangan yang ada pada dirinya. Ia mengerti bahwa hal yang ia cari dan inginkan, merupakan suatu hasrat yang belum ia penuhi. Tokoh 'kau' merasa bahwa setelah melewati perjalanan dan petualangan, keinginannya malah terasa semakin jauh dan sulit ia wujudkan. Hal itu dilihat dari kutipan berikut,

"Bagi sebagian orang, dunia benar-benar kecil. Tapi dunia kecil macam ini bukan-atau belum jadi-milikmu. Hingga kini, dunia buatmu masih terlalu besar dan tak terhubungkan." (Paramaditha, 2017, hal. 159).

'Dunia benar-benar kecil' 'bukan atau belum jadi milikmu' 'terlalu besar' 'tak terhubungkan' merupakan objek-objek yang menandakan kekurangan yang ada pada tokoh 'kau'. Kekurangan itu terus menimbulkan hasrat yang tak pernah terpuaskan. Hasrat akan sebuah kebebasan yang belum ia dapatkan. 'Kau' belum bisa mencapai dan melampaui batasan yang ada.

Tokoh 'kau' mengaku bahwa ia tidak pernah melakukan hal penting seumur hidupnya. 'kau' menyadari bahwa jika dibandingkan dengan petualangan orang lain, petualangannya tidak berarti apa-apa. Hal tersebut terlihat, saat kau bertemu dengan Vijay seorang jurnalis yang telah mengunjungi banyak negara.

"Seumur hidupku aku belum pernah melakukan hal penting," kau mengaku.

Vijay tertawa.

“Jelaskan apa itu penting.”

"Kau termenung. Saat membuat perjanjian dengan iblis hanya ada satu hal yang kau anggap penting: jalan-jalan. Pergi dari rumah untuk merantau. Gentayangan, tak berpikir tentang pulang. Semua ini lebih penting dari apa pun buatmu, dan mungkin juga buat mereka yang terperangkap di kota yang sama, rumah yang sama. Tapi setelah kau sampai di sini, di subway Kota New York tempat manusia dengan beragam cerita bertemu sebagai orang asing, kau tetap merasa apa yang kau lakukan tak penting.” (Paramaditha, 2017, hal. 162)

'Jalan-jalan' 'pergi' 'merantau' 'tak berpikir pulang' 'terperangkap' merupakan objek-objek yang menandakan hasrat kebebasan yang ada didalam diri 'kau'. 'Gentayangan' merupakan metafora dari kebebasan yang ingin ia rasakan karena dengan 'Gentayangan' tak ada batasan yang menghalangi dirinya untuk berpetualang.

Tokoh 'kau' akhirnya memilih dan menentukan tujuannya. 'kau' memutuskan untuk menjalani dan menerima apa yang ia miliki. Meskipun hasrat petualangan yang luar biasa masih ada di dalam dirinya. Tapi ia memutuskan untuk menjalani dan menikmati 
keputusan yang telah ia pilih. Keputusan yang membebaskan dirinya dari hal besar yang ia dambakan. Sebagaimana yang diungkapkan Hill (2002, hal. 69) bahwa bila seseorang telah berhasil melampaui permintaannya, ia dapat mengatakan keinginanannya. Orang seperti itu dapat mengatakan kepada Anda apa yang diinginkannya dan bagaimana keinginan itu mendorong hidupnya.

Tak ada kata selamanya di benakmu saat menikah dengan Fernando. Kau bahkan melihat pernikahanmu sebagai sebuah eksperimen yang barangkali akan gagal. Di luar dugaanmu, kau bertahan dalam pernikahan itu selama tujuh tahun. Setidaknya sampai hari ini, kau menikmati tiap babak baru yang kau lewati bersama Fernando dan Tiffany meski babakbabak itu mungkin bukanlah petualangan yang demikian hebat. (Paramaditha, 2017, hal. 461).

'Tak ada kata selamanya' 'eksperimen' 'bertahan' 'menikmati' 'babak baru' 'lewati' 'bukanlah petualangan hebat' merupakan objek-objek yang menandakan bahwa tokoh 'kau' telah berhasil menentukan keinginannya. Keingianan yang mewujudkan kebebasan yang ia cari dan telah ia temukan. Penanda 'menikmati' dan 'lewati', merupakan bentuk representasi kebebasan tokoh 'kau' serta menunjukkan bahwa penulis telah menikmati dan melewati setiap perjalanan yang telah ia lakukan.

Kau menarik kopermu dan berjalan mengikutinya, berusaha menyesuaikan diri dengan langkahnya yang cepat. Kalian tiba di depan lorong panjang berkarpet merah dengan dinding putih melengkung yang siap memayungimu seperti kapsulatau cangkang. Di ujung sana, kau lihat cahaya.

"ini seperti-“"

"Pesawat luar angkasa?” ia seperti bisa membaca pikiranmu, atau semua orang yang datang ke sini selalu berkomentar begitu. Berjalan di atas karpet merah panjang, kau merasa seperti astronot glamor.

“Tapi ini terminal, 'kan?”

"Ya. Terminal dibangun tahun 1962, dengan fantasi tentang luar angkasa. Tentu kau bisa ihat sendiri"

"Kau merasa mendengar sebuah mesin, sebuah awalan, sebuah perjalanan lain melewati bintang-bintang. Bukan. Itu suaramu sendiri, mencicit, seperti cecurut yang terinjak." (Paramaditha, 2017, hal. 31)

Pada kutipan di atas, 'Pesawat luar angkasa' 'astronot glamor' 'terminal' 'sebuah awalan, sebuah perjalanan lain melewati bintang-bintang' objek-objek tersebut menandakan metonimia tentang suatu kebebasan. Salah satu metonimia yang menandakan kebebasan 'sebuah awalan, sebuah perjalanan lain melewati bintang-bintang', kata tersebut menjelaskan tentang bagaimana 
petualangan tersebut akan dimulai. Petualangan yang cukup panjang dan bisa mendatangkan resiko.

"Pada petugas kau tunjukkan tiket dan paspormu. Ia memeriksa keduanya, namun tiba-tiba alisnya berkerut.” (Paramaditha, 2017, hal. 34)

Terdapat metonimia yaitu, 'tiket dan paspormu' merupakan penanda yang merepresentasikan hasrat kebebasan tokoh 'kau'. 'Tiket dan paspor' menandakan bahwa tokoh 'kau' akan melakukan perjalanan yang jauh. Perjalanan yang terus membawa 'kau' pada petualangan-petualangan lainnya.

“Karena ia tak mau bicara denganmu, kau akan meninggalkan sepatu merah di dapur sebelum keluar dari apartemen itu. Di hari ke pindahanmu, kau akan pergi pagi-pagi sekali. Maria akan terbangun sekitar tengah hari, membuka pintu kamarnya untuk pergi ke dapur (mungkin ia akan ke kamar mandi terlebih dahulu), dan ia akan menemukan sepasang sepatu merah dan kunci rumah di atas meja”. (Paramaditha, 2017, hal. 354)

Pada kutipan di atas, 'meninggalkan sepatu merah' 'keluar dari apartemen' 'pindah' 'kunci rumah' terdapat objek-objek yang menandakan bahwa tokoh 'kau' mencoba membagi kebebasannya kepada orang lain. Kebebasan yang ia ingin bagikan direpresentasikan dengan memberikan sepatu merahnya. Sepatu merah melambangkan kebebasan yang dapat membawa 'kau' kemana saja. Dengan memberikan sepatu merah itu berarti 'kau' berniat membantu seseorang mendapatkan kebebasan seperti kebebasan yang telah 'kau' dapatkan.

Novel Gentayangan karya Intan Paramaditha menggambarkam hasrat kebebasan dengan petualangan atau perjalanan. Dalam cerita novel Gentayangan tokoh 'kau' mendapatkan tiga jalan cerita yang dapat dipilih oleh pembaca atau disediakan oleh Intan Paramaditha sebagai penulis. Sebelum memasuki jalur yang telah ditentukan oleh pengarang. Tokoh 'Kau' direpresentasikan memiliki hasrat kebebasan. Hal ini tergambar pada metonimia dan metafora sebelum tokoh 'Kau' memilih jalur yang disediakan. Metonimia terdapat pada 'bertualang' 'gentayangan' 'bernaung tapi tak berumah' 'keinginanmu' 'perjalananmu' 'kau boleh memilih hadiah, juga jalan cerita, sesuai keinginanmu'. Selain metonimia hasrat kebebasan juga tergambar oleh metafora, metafora dalam terdapat pada kata "sepatu merah". Kemudian, hasrat kebebasan juga direpresentasikan dalam jalur pertama, hasrat kebebasan tokoh 'kau' ditandai dengan metonomia 'Stasiun kereta Sutphin Boulevard' 'koper atau ransel besar' 'kereta' 'Bandara JFK', 'yakin' 'keluar' 'dinding' 'mengurungmu' 'belajar' 'menabung' 'harus pergi' dll. Selanjutnya, Jalur dua hasrat kebebasan direpresentasikan dengan metonimia yaitu 'Pesawat luar angkasa' 'astronot glamor' 'terminal' dan yang terakhir, jalur tiga hasrat 
kebebasan yaitu 'tiket dan paspormu' dan 'meninggalkan sepatu merah’ 'keluar dari apartemen’ 'pindahmu’ 'kunci rumah'.

SIMPULAN

\section{DAFTAR PUSTAKA}

Bracher, M. 2009. Jacques Lacan, Diskursus, dan Perubahan Sosial, Pengantar Kritik Budaya Psikoanalisis. $\quad$ Yogyakarta: Jalasutra. beda.
Berdasarkan pembahasan novel Gentayangan karya Intan Paramaditha maka dapat dilihat bahawa hasrat kebebasan tokoh 'Kau' ditemukan melalui petualangan. Di dalam petualangannya, tokoh 'Kau' terus melakukan pencarian akan dirinya untuk mendapatkan atau merasakan kebebasan yang ia inginkan. Kita dapat mengetahui beberapa representasi dari sebuah kebebasan dengan bantuan bahasa. Bahasa yang digunakan oleh pengarang untuk menyampaikan bentuk hasrat kebebasan. Melalui bahasa tokoh-tokoh yang ada di dalam novel Gentayangan merepresentasikan hasrat kebebasan dengan cara yang berbeda-

Metafora dan metonimia yang terlihat dalam novel ini menunjukan adanya hasrat kebebasan yang direpresentasikan pada tokoh 'Kau'. Hasrat kebebasan itu ditunjukan melalui kata-kata yang terkait dengan perjalanan dan inspirasi kebebasan dari orang lain. Dalam hal ini terdapat tiga jalur petualangan. Tiga jalur petualangan menunjukan kebebasan yang berbeda-beda. Jalur pertama, tokoh 'Kau' baru memulai petualangan untuk merasakan kebebasan. Tokoh 'Kau' semakin yakin bahwa kebebasan perlu didapatkan dan melalui kebebasan orang lain tokoh 'kau' semakin menyadari seperti apa kebebasan itu. Pada jalur kedua, tokoh 'Kau' melakukan perjalanan yang panjang, perjalanan tersebut mengharuskan tokoh 'kau' untuk memilih kebebebasan yang dapat mendatangkan resiko. Jalur ketiga, tokoh 'Kau' masih melakukan perjalanan, di tengah perjalanannya ia telah merasakan kebebasan dan mencoba membagikan kebebasan yang ia rasakan kepada orang lain. Dari ketiga jalur tersebut dapat disimpulkan terdapat tiga jenis kebebasan dalam novel Gentayangan yaitu kebebasan dalam melakukan perjalanan, kebebasan yang dipilih dan beresiko, serta kebebasan yang dapat dibagikan kepada orang lain.Hal ini menunjukan bahwa setia hasrat untuk mewujudkan kebebasan selau berkaitan dengan resiko atau konsekuansi dan tindakan dan kebebasan orang lain.

Kebebasan yang didapatkan tokoh 'kau' merupakan sebuah representasi kebebasan pengarang. Intan Paramaditha sejak awal ingin membagikan kebebasannya kepada kita lewat tokoh 'Kau'. Kebebasan yang ditampilkan dalam Gentayangan, merupakan sebuah ajakan untuk mulai memahami dan mewujudkan sebuah kebebasan yang dimiliki setiap orang. 
Hasrat Kebebasan Tokoh ‘Kau’ Dalam Novel Gentayangan Karya Intan Paramaditha

Hartono, A. 2007. Skizoanalisis Deleuze+ Guattari: Sebuah Pengantar Genealogi Hasrat. Yogyakarta: Jalasutra.

Hill, P. 2002. Lacan Untuk Pemula. Yogyakarta: Kanisius.

Lacan, J. 2001. A Selection Ecrits. London: Routledge.

Manik, R. A. 2016. Hasrat Nano Riantiarno dalam Cermin Cinta: Kajian Psikoanalisis Lacanian. Jurnal Poetika, 74-84.

Minderop, Albertine. 2016. Psikologi Sastra.Jakarta: Yayasan Pustaka Obor Indonesia
Paramaditha, I. 2017. Gentayangan. Jakarta: PT Gramedia Pustaka Utama

.Rahimi, S. 2009, April 29. The Unconscious: Metaphor and Metonymy. Retrieved Januari 07, 2019, from Somatosphere: http://somatosphere.net/2009/04/ unconscious-metaphor-andmetonymy.html

Sarup, M. 2011. Panduan Pengantar untuk Memahami Postrukturalisme dan Posmodernisme. Yogyakarta: Jalasutra. 